\title{
Identification of bisphenols and derivatives in greenhouse dust as a potential source for human occupational exposure
}

\author{
Noelia Caballero-Casero ${ }^{1}$ (D) $\cdot$ Soledad Rubio $^{1}$ (D)
}

Received: 19 October 2021 / Revised: 14 December 2021 / Accepted: 21 December 2021 / Published online: 29 January 2022

(c) The Author(s) 2022

\begin{abstract}
Bisphenol A (BPA) and alternative bisphenols are widely used in the industrial production of polycarbonates and resin polymers. Adverse effects on human health have been described for BPA and owing to the structural similarity of alternative bisphenols and derivatives, a similar toxicity profile is expectable. Dust can act as a sink for bisphenols owing to the large surface area to mass ratio. Human risk exposure to bisphenols via indoor dust has been widely assessed in the last decade. The environmental conditions inside greenhouses, among other factors, facilitate that chemicals are released from greenhouse building materials to dust. This study aims to explore for the first time the potential of greenhouse dust as a new source of bisphenols for human exposure. For this purpose, a supramolecular solvent-based method was applied to the extraction of twenty-one bisphenols from greenhouse dust, prior to their determination by liquid chromatography-tandem mass spectrometry. Nineteen bisphenols were found in the five greenhouse dust samples analysed, with concentrations ranging from $5275 \mathrm{ng} \mathrm{g}^{-1}$ (BPA) to $0.25 \mathrm{ng} \mathrm{g}^{-1}$ (trichlorobisphenol A). The average daily dose (ADD) via dust ingestion for bisphenol compounds was calculated, in order to estimate the occupational exposure for inadvertent dust ingestion. Despite the calculated ADD value for BPA (47.81 $\left.\mathrm{ng} \mathrm{kg}^{-1} \mathrm{day}^{-1}\right)$ being below the tolerable daily intake proposed by EFSA $\left(4 \cdot 10^{3} \mathrm{ng} \mathrm{kg}^{-1} \mathrm{day}^{-1}\right)$, this value was considerably higher than those previously reported for indoor dust, which brings to light the importance of considering greenhouse dust as bisphenols source of exposure for greenhouse workers.
\end{abstract}

Keywords Greenhouse dust $\cdot$ Supramolecular solvent $\cdot$ Liquid chromatography-tandem mass spectrometry $\cdot$ Risk assessment $\cdot$ Bisphenols $\cdot$ Occupational exposure

\section{Introduction}

Bisphenol A (BPA) is a synthetic high-production chemical used as a monomer in the production of polycarbonate plastic, epoxy resins and other plastics polymers. BPA is an androgenic and estrogenic disruptor [1], and it has been classified by the European Union (EU) as a reproductive toxicant category 1B [2]. Various toxicological effects on humans have been reported for BPA: adverse effects on the

Published in the topical collection featuring Promising Early-Career (Bio)Analytical Researchers with guest editors Antje J. Baeumner, María C. Moreno-Bondi, Sabine Szunerits, and Qiuquan Wang.

Noelia Caballero-Casero

a42caasn@uco.es

1 Department of Analytical Chemistry, Institute of Fine Chemistry and Nanochemistry, Edificio Anexo Marie Curie, Campus de Rabanales, 14071 Córdoba, Spain reproductive, immune and cognitive system; obesity, metabolic dysfunctions, diabetes and behavioural development [3]. The raising concern about BPA effects had led to the development of regulatory legislation and the establishment of maximum levels permitted for several applications. As a result, the industry has replaced BPA with other bisphenol compounds in some applications. For example, BPS is widely used as a colour developer in thermal paper [4]. BPA-chlorinated derivatives are formed due to the reaction of BPA with chlorine atoms, for example with the sodium hypochlorite used for disinfection in tap water. Bisphenol diglycidyl ethers are used as building blocks of epoxy resins and other plastic polymers, which can be transformed into hydrolytic and chlorinated forms under humid or acidic conditions [5-7]. Unfortunately, the alternative bisphenols are structurally similar to BPA, so exhibit a similar toxicity profile but being even less well-known than BPA $[8,9]$.

Indoor dust has been proved to act as a sink for multiple chemical classes owing to the large surface area to mass 
ratio. Indoor dust from residential, vehicles and workplaces (offices) have been detected as important sources of human exposure to semivolatile organic compounds such as pesticides, (new)flames retardants and plasticizers [7, 10, 11]. Typically, chemicals reach the dust either via direct application into the indoor environment, for example pesticides; or by releasing from materials and consumer products (volatilization of chemicals, transfer for contact material-dust, abrasion of particles from a product) as in the case of bisphenols $[12,13]$.

Human exposure to dust occurs through two different pathways: (i) via dermal contact and (ii) via dust ingestion [14]. Inhalation exposure to dust is minimum and usually is neglected, albeit under some conditions may be an important exposure route. Dermal exposure depends on the skin surface exposed, the diameter of dust particles and the dust adherence to skin factor [15]. The average rates of dust ingestion are yet uncertain, although is strongly affected by the dust particle diameter and adherence to skin and the hand-to-mouth behaviour frequency [14]. Although dust ingestion might be a minor pathway for bisphenols compared to bisphenol dietary intake, from an occupational point of view, the high concentration and/or exposure time may contribute substantially to the total exposure. Human risk exposure to bisphenols via indoor dust has been widely assessed in the last decade. Dust samples have been collected from resdentials, vehicles, offices, plastic-related industries and schools, among others, over the world [7, 16, 17]. However, there are still potential sources of bisphenol exposure that remain unknown.

The aim of this research focuses on the existing gap regarding the contribution of dust ingestion to the total greenhouse workers' exposure to bisphenols, chlorinated derivatives and diglycidyl ethers. Industrial greenhouses are made of plastic materials such as polycarbonates and polymers. The environmental conditions inside greenhouses, such as continuous radiation, high temperature and humidity, together with the use of phytosanitary products promote the degradation of greenhouse building materials. Thus, chemicals can release from greenhouse building materials to dust.

The occurrence of 21 bisphenols and derivatives in dust from greenhouses was determined by the combined use of supramolecular solvents (SUPRAS) and liquid chromatography-tandem mass spectrometry (LC-MS/MS). SUPRAS are environmentally responsive nanostructured liquids made up of colloidal suspensions of amphiphiles produced in a process of spontaneous self-assembly and coacervation [18]. The supramolecular aggregate formation is driven by non-covalent interactions; thus, they are reversible and can be tuneable by tailoring the synthesis conditions. SUPRAS have outstanding properties for multicompounds solubilisation, mainly (i) a high number of binding sites; (ii) two microenvironments of different polarity; and (iii) ability to behave as restricted access materials by excluding interferents through physical and chemical mechanisms [18-20]. The combination of these properties makes SUPRAS excellent solvents that can solubilise simultaneously multiple organic compounds by dispersion forces, hydrogen bondings, polar interactions, etc., getting clean extracts. In this way, they can efficiently extract bisphenols and derivatives in a wide polarity range ( $\log K_{\mathrm{o} / \mathrm{w}}$ from 1.25 to 6.56 ), as previously proved for their analysis in common human exposure sources to bisphenols [21].

To the best of our knowledge, this is the first proposal to identify the potential risk of occupational exposure to bisphenols in greenhouse dust. The obtained results and main conclusions are exposed and discussed below.

\section{Materials and methods}

\section{Chemicals and reagents}

All chemicals were of analytical grade and were used as supplied. The name and acronyms of the twenty-one bisphenols investigated are specified in Table 1. BPA, BPF, BPP, BPS, BPZ, BPAF, BPAP, BADGE, BADGE $\cdot \mathrm{H}_{2} \mathrm{O}$, BADGE $2 \mathrm{H}_{2} \mathrm{O}$, BADGE $\cdot \mathrm{HCl}, \mathrm{BADGE} \cdot 2 \mathrm{HCl}, \mathrm{BADGE} \cdot \mathrm{H}_{2} \mathrm{O} \cdot \mathrm{HCl}$, BFDGE and BFDGE $2 \mathrm{H}_{2} \mathrm{O}$ were supplied by Sigma-Aldrich (Steinheim, Germany). MCBPA, DCBPA, TCBPA and TeCBPA were obtained from Cymit (Barcelona, Spain). BPB and BPE were supplied by TCI Europe (Zwijndrecht, Belgium). Labelled isotopically bisphenol A $\left({ }^{13} \mathrm{C}-\mathrm{BPA}\right)$ and bisphenol A diglycidyl ether ( $\mathrm{d}_{6}$-BADGE) were acquired from Cambridge isotope laboratories (UK). Methanol, 1-hexanol (H) and tetrahydrofuran (THF) were purchased from VWRProlabo (Bois, France). Ammonium formate ( $\geq 99 \%)$ was supplied by Sigma-Aldrich (St. Louis, USA) and formic acid (98\%) by Panreac Química (Barcelona, Spain). Ultra-pure quality water was obtained from a milli-Q water purification system (Millipore, Madrid, Spain), and Lichrosolv® water was supplied by Merck KGaA (Darmstadt, Germany).

Stock solutions were prepared for individual bisphenols or internal standards in methanol at $1-2.5 \mathrm{~g} \mathrm{~L}^{-1}$ range and stored at $-20{ }^{\circ} \mathrm{C}$ until their use. Intermediate solutions of bisphenol mixtures were prepared in methanol at a concentration of $10 \mathrm{mg} \mathrm{L}^{-1}$. Working solutions were prepared weekly by appropriate dilution of the intermediate solutions with methanol.

\section{Sample collection}

Dust samples $(n=5)$ were collected in two representative types of greenhouses (Fig. 1) from Andalusia, Spain. The sawtooth greenhouse is made of polycarbonate over a metallic structure (Fig. 1a). Ventilation and humidity levels are 


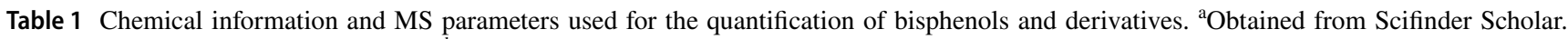
Available from: https://scifinder.cas.org. ${ }^{b}$ Quantifier (in bold) and qualifier ions

\begin{tabular}{|c|c|c|c|c|c|c|c|c|c|}
\hline Compound & Chemical Structure $^{\mathrm{a}}$ & MW & $\begin{array}{l}\log \\
\mathrm{Ko} / \mathbf{w}^{\mathrm{a}}\end{array}$ & $\mathbf{p K a}^{\mathbf{a}}$ & $\begin{array}{l}\text { Precursor } \\
\text { ion } \\
(\mathrm{m} / \mathbf{z})\end{array}$ & $\begin{array}{l}\text { Product } \\
\text { ions } \\
(\mathbf{m} / \mathbf{z})\end{array}$ & $\begin{array}{l}\text { Declustering } \\
\text { Potential } \\
\text { (V) }\end{array}$ & $\begin{array}{l}\text { Collision } \\
\text { Energy } \\
(V)\end{array}$ & $\begin{array}{l}\text { Collision Cell } \\
\text { Exit } \\
\text { Potential (V) }\end{array}$ \\
\hline $\begin{array}{l}\text { 2,2'-Bis(4-hydroxyphenyl)propane } \\
\text { (BPA) }\end{array}$ & & 228.29 & 3.641 & 10.29 & 227 & $\begin{array}{l}\mathbf{2 1 2 . 0} \\
133.0\end{array}$ & $\begin{array}{l}-100 \\
-100\end{array}$ & $\begin{array}{l}-25 \\
-40\end{array}$ & $\begin{array}{l}-15 \\
-5\end{array}$ \\
\hline $\begin{array}{l}\text { 2,2'-Bis(4-hydroxyphenyl)butane } \\
\text { (BPB) }\end{array}$ & & 242.31 & 4.150 & 10.27 & 241 & $\begin{array}{l}\mathbf{2 1 2 . 0} \\
93.0\end{array}$ & $\begin{array}{l}-50 \\
-50\end{array}$ & $\begin{array}{l}-25 \\
-70\end{array}$ & $\begin{array}{l}-15 \\
-15\end{array}$ \\
\hline $\begin{array}{l}\text { 4,4'-Ethylidenebisphenol } \\
\text { (BPE) }\end{array}$ & & 214.26 & 3.230 & 10.10 & 213 & $\begin{array}{l}\mathbf{1 9 8 . 0} \\
119.0\end{array}$ & $\begin{array}{l}-50 \\
-50\end{array}$ & $\begin{array}{l}-25 \\
-40\end{array}$ & $\begin{array}{l}-15 \\
-15\end{array}$ \\
\hline $\begin{array}{l}\text { 4,4'-Dihydroxydiphenylmethane } \\
\text { (BPF) }\end{array}$ & & 200.23 & 2.764 & 9.91 & 199 & $\begin{array}{l}\mathbf{9 3 . 0} \\
105.0\end{array}$ & $\begin{array}{l}-50 \\
-50\end{array}$ & $\begin{array}{l}-25 \\
-25\end{array}$ & $\begin{array}{l}-15 \\
-15\end{array}$ \\
\hline $\begin{array}{l}\text { 1,4-Bis(2-(4-hydroxyphenyl)-2-propyl)benzene } \\
\text { (BPP) }\end{array}$ & & 346.46 & 6.564 & 10.31 & 345 & $\begin{array}{l}329.9 \\
133.0\end{array}$ & $\begin{array}{l}-100 \\
-100\end{array}$ & $\begin{array}{l}-40 \\
-70\end{array}$ & $\begin{array}{l}-15 \\
-25\end{array}$ \\
\hline $\begin{array}{l}\text { Bis(4-hydroxyphenyl)sulfone } \\
\text { (BPS) }\end{array}$ & & 250.27 & 2.139 & 7.64 & 249 & $\begin{array}{l}\mathbf{1 0 8 . 0} \\
92.0\end{array}$ & $\begin{array}{l}-100 \\
-100\end{array}$ & $\begin{array}{l}-40 \\
-55\end{array}$ & $\begin{array}{l}-5 \\
-5\end{array}$ \\
\hline $\begin{array}{l}\text { 1,1'-Bis(4-hydroxyphenyl)-cyclohexane } \\
\text { (BPZ) }\end{array}$ & & 268.35 & 4.870 & 9.91 & 267 & $\begin{array}{l}\mathbf{1 7 2 . 9} \\
144.9\end{array}$ & $\begin{array}{l}-100 \\
-100\end{array}$ & $\begin{array}{l}-40 \\
-55\end{array}$ & $\begin{array}{l}-15 \\
-5\end{array}$ \\
\hline $\begin{array}{l}\text { 2,2'-Bis(4-hydroxyphenyl)hexafluoropropane } \\
\text { (BPAF) }\end{array}$ & & 336.23 & 3.975 & 8.74 & 335 & $\begin{array}{l}\mathbf{2 6 4 . 9} \\
69.0\end{array}$ & $\begin{array}{l}-100 \\
-100\end{array}$ & $\begin{array}{l}-40 \\
-70\end{array}$ & $\begin{array}{l}-15 \\
-15\end{array}$ \\
\hline
\end{tabular}

controlled with an evaporative cooling system and a set of fans (Fig. 1b). Moreover, $1.8 \mathrm{~m}$ over the floor, there are lamps to provide extra radiation because of its positive effect on seedling growth. A regular vacuum cleaner was operated, equipped with a paper deposition bag with an inline fibre filter to hold dust inside, to collect dust from the surface of lamps (sample 1), polycarbonate panels (sample 2), evaporative cooling system (sample 3 ) and fans (sample 4). The second greenhouse is a shade house type made of polyethylenebased geotextile over a metallic structure (Fig. 1c-d); thus, there is a constant flow of air between the inside and outside; and the humidity level is equivalent to the outside environment. Sample 5 was collected directly from the geotextile walls. Special care was taken in order not to collect ground particles from soil. To avoid cross-contamination, dust was collected in separate bags for each location and the vacuum cleaner was cleaned with methanol between samples. The collection bags were labelled with a pencil to avoid sample contamination from the pen ink.

Fibres, hair and big particles were removed from dust samples with the help of metallic tweezers. Then, dust samples were sieved using a pre-cleaned metallic double sieve of 1000 and $500 \mu \mathrm{m}$ of pore size. Finally, the samples were individually stored in dark glass bottles at room temperature until their analysis.

\section{Control of background bisphenol contamination}

Bisphenols are ubiquitous compounds; therefore, it is crucial to reduce the potential source of contamination. All the experiments were carried out in a dedicated room where all the surfaces every day were thoroughly cleaned using methanol. Whenever possible, only glass labware was used, which was successively sonicated in distilled water with mild detergent, distilled water and methanol (twice each step), immediately of being used. The unavoidable plastic material (i.e. microtubes and pipettes tips) was rinsed with methanol before their use. Bisphenols can leach from several components of the chromatographic system; thus, symmetry C18 column $(3.5 \mu \mathrm{m}, 75 \mathrm{~mm} \times 4.6 \mathrm{~mm}$. Waters (Milford, MA, USA)) was placed between the binary pump and the automatic sampler. Therefore, bisphenols coming from the chromatographic devices elute later on the chromatogram. In addition, ultra-pure quality water was filtered through Empore SDB-XC disks (Análisis Vínicos, Tomelloso, Spain), for removing potential BPA. 
Table 1 (continued)

\begin{tabular}{|c|c|c|c|c|c|c|c|}
\hline $\begin{array}{l}\text { 1,1'-Bis(4-hydroxyphenyl)-1-phenyl-ethane } \\
\text { (BPAP) }\end{array}$ & 290.364 .331 & 10.22 & 289 & $\begin{array}{l}\mathbf{2 7 3 . 9} \\
195.0\end{array}$ & $\begin{array}{l}-100 \\
-100\end{array}$ & $\begin{array}{l}-25 \\
-40\end{array}$ & $\begin{array}{l}-15 \\
-15\end{array}$ \\
\hline $\begin{array}{l}\text { 2-Chloro-4-[1-(4-hydroxyphenyl)-1- } \\
\text { methylethyl]phenol } \\
\text { (MCBPA) }\end{array}$ & 262.734 .335 & 9.79 & 261 & $\begin{array}{l}\mathbf{1 8 2 . 0} \\
245.8\end{array}$ & $\begin{array}{l}-100 \\
-100\end{array}$ & $\begin{array}{l}-40 \\
-25\end{array}$ & $\begin{array}{l}-15 \\
-15\end{array}$ \\
\hline $\begin{array}{l}\text { 2,6-Dichloro-4-[1-(4-hydroxyphenyl)-1- } \\
\text { methylethyl]phenol } \\
\text { (DCBPA) }\end{array}$ & $297.18 \quad 5.027$ & 8.98 & 296 & $\begin{array}{l}244.0 \\
216.1\end{array}$ & $\begin{array}{l}-100 \\
-100\end{array}$ & $\begin{array}{l}-24 \\
-28\end{array}$ & $\begin{array}{l}-5 \\
-5\end{array}$ \\
\hline $\begin{array}{l}\text { 2,6-Dichloro-4-[1-(3-chloro-4-hydroxyphenyl)-1- } \\
\text { methylethyl]phenol } \\
\text { (TCBPA) }\end{array}$ & 331.625 .721 & 8.93 & 330 & $\begin{array}{l}\mathbf{2 5 1 . 8} \\
279.8\end{array}$ & $\begin{array}{l}-85 \\
-85\end{array}$ & $\begin{array}{l}-44 \\
-36\end{array}$ & $\begin{array}{l}-11 \\
-21\end{array}$ \\
\hline $\begin{array}{l}\text { 4,4'-(1-methylethylidene)bis[2,6-dichloro-phenol } \\
\text { (TeCBPA) }\end{array}$ & 366.076 .413 & 8.59 & 365 & $\begin{array}{l}313.7 \\
285.6\end{array}$ & $\begin{array}{l}-85 \\
-85\end{array}$ & $\begin{array}{l}-36 \\
-44\end{array}$ & $\begin{array}{l}-17 \\
-17\end{array}$ \\
\hline $\begin{array}{l}\text { 2,2'-Bis(4-glycidyloxyphenyl)propane } \\
\text { (BADGE) }\end{array}$ & 340.413 .710 & - & 359 & $\begin{array}{l}\mathbf{1 9 0 . 9} \\
135.0\end{array}$ & $\begin{array}{l}52 \\
51\end{array}$ & $\begin{array}{l}21 \\
43\end{array}$ & $\begin{array}{l}10 \\
24\end{array}$ \\
\hline $\begin{array}{l}\text { 2-[4-(2,3-Dihydroxypropyloxy)phenyl]-2-[4- } \\
\text { (glycidyloxy)phenyl]propane } \\
\text { (BADGE } \cdot \mathrm{H}_{2} \mathrm{O}\end{array}$ & $358.43 \quad 3.185$ & 13.53 & 376 & $\begin{array}{l}\mathbf{2 0 8 . 9} \\
191.1\end{array}$ & $\begin{array}{l}56 \\
56\end{array}$ & $\begin{array}{l}19 \\
27\end{array}$ & $\begin{array}{l}12 \\
10\end{array}$ \\
\hline $\begin{array}{l}\text { 2,2'-Bis[4-(2,3-dihydroxypropoxy)phenyl]propane } \\
\left(\text { BADGE- } 2 \mathrm{H}_{2} \mathrm{O}\right)\end{array}$ & 376.442 .515 & 13.23 & 394 & $\begin{array}{l}\mathbf{2 0 9 . 0} \\
135.0\end{array}$ & $\begin{array}{l}61 \\
61\end{array}$ & $\begin{array}{l}23 \\
45\end{array}$ & $\begin{array}{l}12 \\
22\end{array}$ \\
\hline $\begin{array}{l}\text { 2-[4-(3-Chloro-2-hydroxypropyloxy)pheny]-2-[4- } \\
\text { (glycidyloxy)phenyl]propane } \\
\text { (BADGE } \cdot \mathrm{HCl} \text { ) }\end{array}$ & 376.874 .025 & 13.33 & 394 & $\begin{array}{l}\mathbf{2 2 6 . 9} \\
135.1\end{array}$ & $\begin{array}{l}56 \\
56\end{array}$ & $\begin{array}{l}19 \\
43\end{array}$ & $\begin{array}{l}12 \\
22\end{array}$ \\
\hline $\begin{array}{l}\text { 2,2'-Bis[4-(3-chloro-2- } \\
\text { hydroxypropoxy)phenyl]propane } \\
\text { (BADGE-2HCl) }\end{array}$ & 413.334 .340 & 12.83 & 430 & $\begin{array}{l}227.1 \\
135.1\end{array}$ & $\begin{array}{l}56 \\
56\end{array}$ & $\begin{array}{l}21 \\
49\end{array}$ & $\begin{array}{l}12 \\
22\end{array}$ \\
\hline $\begin{array}{l}\text { 2-[4-(3-Chloro-2-hydroxypropyloxy)phenyl]-2-[4-(2,3- } \\
\text { dihydroxypropyloxy)phenyl] propane } \\
\left(\text { BADGE } \cdot \mathrm{HCl} \cdot \mathrm{H}_{2} \mathrm{O}\right)\end{array}$ & 394.893 .500 & 13.13 & 412 & $\begin{array}{l}\mathbf{1 3 5 . 0} \\
208.9\end{array}$ & $\begin{array}{l}61 \\
56\end{array}$ & $\begin{array}{l}45 \\
19\end{array}$ & $\begin{array}{l}22 \\
12\end{array}$ \\
\hline $\begin{array}{l}\text { Bis[4-(glycidyloxy)phenyl]methane } \\
\text { (BFDGE) }\end{array}$ & $312.36 \quad 2.449$ & - & 330 & $\begin{array}{l}\mathbf{1 6 3 . 1} \\
133.0\end{array}$ & $\begin{array}{l}51 \\
51\end{array}$ & $\begin{array}{l}19 \\
23\end{array}$ & $\begin{array}{l}8 \\
22\end{array}$ \\
\hline $\begin{array}{l}\text { Bis[4-(2,3-dihydroxypropoxy)phenyl]methane } \\
\left.\text { (BFDGE } 2 \mathrm{H}_{2} \mathrm{O}\right)\end{array}$ & 348.391 .254 & 13.52 & 366 & $\begin{array}{l}\mathbf{1 8 1 . 1} \\
107.1\end{array}$ & $\begin{array}{l}51 \\
51\end{array}$ & $\begin{array}{l}21 \\
41\end{array}$ & $\begin{array}{l}10 \\
18\end{array}$ \\
\hline 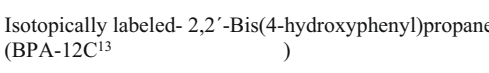 & $240.20-$ & - & 239 & $\begin{array}{l}\mathbf{2 2 4 . 1} \\
138.8\end{array}$ & $\begin{array}{l}-95 \\
-95\end{array}$ & $\begin{array}{l}-26 \\
-40\end{array}$ & $\begin{array}{l}-5 \\
-5\end{array}$ \\
\hline $\begin{array}{l}\text { Isotopicaly labeled- } 2,2^{\prime} \text {-Bis }(4- \\
\text { glycidyloxyphenyl)propane } \\
\text { (d }{ }_{6} \text {-BADGE) }\end{array}$ & 346.45 - & - & 364 & $\begin{array}{l}\mathbf{1 9 7 . 2} \\
141.2\end{array}$ & $\begin{array}{l}51 \\
51\end{array}$ & $\begin{array}{l}19 \\
47\end{array}$ & $\begin{array}{l}18 \\
8\end{array}$ \\
\hline
\end{tabular}

\section{SUPRAS -based microextraction of bisphenol compounds}

First, hexanol-based SUPRAS-RAM was synthesized by mixing 1-hexanol (3 mL, 10\% v/v/v), THF $(6 \mathrm{~mL}, 20 \%$ $\mathrm{v} / \mathrm{v} / \mathrm{v})$ and water $(21 \mathrm{~mL}, 70 \% \mathrm{v} / \mathrm{v} / \mathrm{v})$ in a $50-\mathrm{mL}$ glass centrifuge tube. Supramolecular aggregates were spontaneously formed and the mixture was centrifuged for $30 \mathrm{~min}$ at $3500 \mathrm{rpm}$ to accelerate SUPRAS phase separation from the bulk solution. The obtained SUPRAS volume $(6.2 \mathrm{~mL})$, able to treat $\sim 15$ samples, was collected with a syringe and kept at room temperature in an airtight vial until its use.

Dust samples were analysed according to the method previously described by Caballero-Casero et al. [21] with slight 
Fig. 1 Images of two different greenhouses: a polycarbonate sawtooth greenhouse (a) and its evaporative cooling system (b); and a polyethylene-geotextile shade house greenhouse $(\mathbf{c})$. The photo (d) shows the inside of the shade house greenhouse
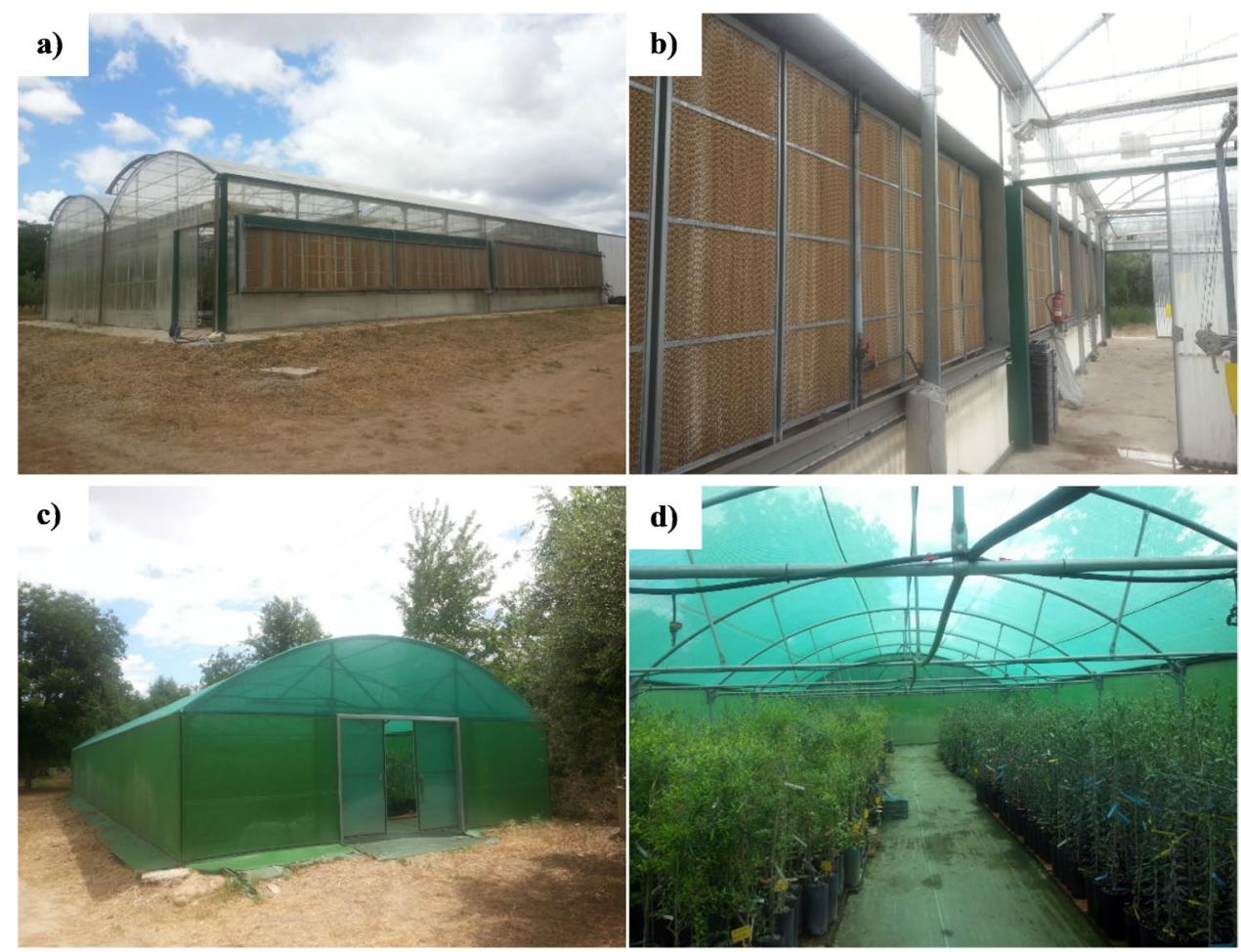

modifications. Briefly, $100 \mathrm{mg}$ of dust sample was weighted in a 2-mL microtube Safe-Lock from Eppendorf Iberia (Madrid, Spain), and extracted with $0.4 \mathrm{~mL}$ of SUPRAS by vortex-shaking for $10 \mathrm{~min}$ at $2500 \mathrm{rpm}$. Three small glass balls ( $3 \mathrm{~mm}$ in diameter) were added to facilitate the extraction. Afterwards, the mixture was centrifuged at $14,160 \mathrm{~g}$ for $5 \mathrm{~min}(36 \times 2.2 / 1.5 \mathrm{~mL}$ angle rotor high-speed brushless centrifuge MPW-350R from MPW Med- Instruments. Warschaw, Poland) to accelerate phase separation. Two aliquots of $0.075 \mathrm{~mL}$ of the SUPRASs extract were transferred to a $15-\mathrm{mL}$ glass centrifuge tube. Both extracts were evaporated to dryness under a gentle nitrogen stream at $60^{\circ} \mathrm{C}(\sim 1 \mathrm{~h})$ and the analytes were redissolved in $0.16 \mathrm{~mL}$ of methanol:water $(50: 50 \mathrm{v} / \mathrm{v})$ or methanol:buffer $(50: 50 \mathrm{v} / \mathrm{v})$ for bisphenols/chlorinated derivatives or diglycidyl ethers, respectively. Ammonium formate/ formic acid (12.5 mM, pH 3.75) buffer was used to promote the formation of $\left[\mathrm{M}+\mathrm{NH}_{4}\right]^{+}$diglycidyl ether adducts, which are necessary to improve diglycidyl ether sensitivity in MS/MS detection [22]. The extracts were introduced into a glass vial with an insert prior to being analysed by LC-ESI $( \pm)-\mathrm{MS} / \mathrm{MS}$. Figure 2 shows an overall scheme of the analytical method.

\section{Quantification of bisphenols by LC-ESI-MS/MS}

Bisphenols were quantified by liquid chromatography coupled to mass spectrometry in tandem (LC-MS/MS). For this purpose, a liquid chromatograph (Agilent HP 1200 series, Palo Alto, CA, USA) equipped with a binary solvent pumping system and an autosampler was used. Chromatographic separation was performed at $35^{\circ} \mathrm{C}$ on a reverse-phase column ACE 3 C18-PFP, $150 \mathrm{~mm} \times 3.0 \mathrm{~mm}, 3.5 \mu \mathrm{m}$ (ACE, UK). It was preceded by a $\mathrm{C} 18$ Guard Cartridge ACE 3 C18-PFP, $3.0 \mathrm{~mm} \times 4.6 \mathrm{~mm}, 4 \mu \mathrm{m}$ (ACE, UK). The injection volume was $10 \mu \mathrm{L}$. Both bisphenols/halogenated derivatives and diglycidyl compounds were analysed under the same chromatographic conditions. The mobile phase consisted of water (A) and methanol (B) at a flow rate of $0.3 \mathrm{~mL} \mathrm{~min}^{-1}$, and the gradient elution was programmed as follows: starts at $50 \%$ of B and increases up to $60 \%$ in $2 \mathrm{~min}$. Then, a linear gradient from 60 to $80 \%$ for $2 \mathrm{~min}$ and from 80 to $90 \%$ for 18 min, reaching $100 \%$ of B for 1 min. Finally, the column was equilibrated under the initial conditions for $5.5 \mathrm{~min}$. Mass spectrometry analyses were accomplished by using a hybrid triple quadrupole/linear ion trap (Applied Biosystems MSD Sciex 4000QTRAP, Foster City, CA, USA) with a TurboIonSpray (TIS) interface. All data were acquired and processed using the Analyst 1.5.1 Software (Applied Biosystems). The MS/MS system was operated in multiple reaction monitoring (MRM) positive mode to quantify ammonium adducts of diglycidyl ethers. Bisphenols/chlorinated derivatives were determined by MRM negative ion mode. Quantitative analyses were carried out using two specific combinations of a precursor-product ion transition for each compound, with a dwell time set up at $30 \mathrm{~ms}$. Common MS parameters were as follows: probe vertical y-axis position, $2 \mathrm{~mm}$; probe horizontal $\mathrm{y}$-axis position, $6 \mathrm{~mm}$; curtain gas $\left(\mathrm{N}_{2}\right), 27 \mathrm{psig}$; ion source gas 1 (nebulizer gas), $40 \mathrm{psig}$; ion source gas 2 (turbo gas), $55 \mathrm{psig}$; temperature of the turbo gas, $600^{\circ} \mathrm{C}$; ion spray 


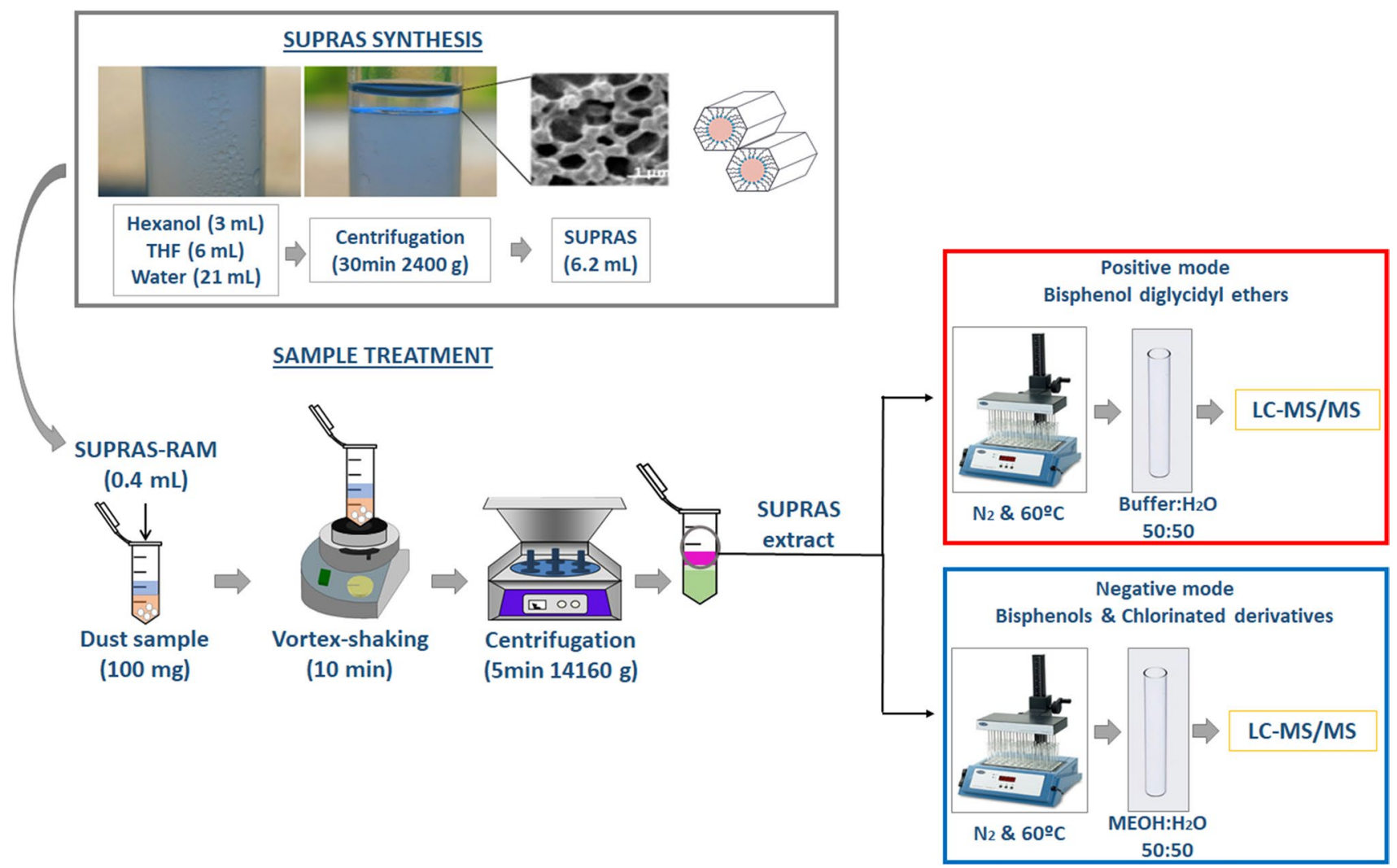

Fig. 2 General scheme of the analytical methodology, the synthesis of the SUPRAS (upper part of the scheme) and sample treatment and quantification (at the bottom)

voltage: \pm 4500 V. Parameter values for the analyser were as follows: 1.0 unit resolution for the first and third quadrupoles; collision gas $3.0 \times 10^{-5}$ Torr; collision energy $-26 \mathrm{~V}$. The compound specific MS/MS parameters are shown in Table 1. Isotopic dilution calibration was performed for the quantification of bisphenol compounds, by analysing analytical standards in methanol:water $(50: 50, \mathrm{v} / \mathrm{v})$ or methanol:buffer $(50: 50 \mathrm{v} / \mathrm{v})$ for bisphenols/chlorinated derivatives or diglycidyl ethers, respectively. The internal standards ${ }_{12} \mathrm{C}^{13}$-BPA and $\mathrm{d}_{6}$-BADGE were respectively added.

\section{Analytical method performance}

Calibration curves $(n=10)$ were built by analysing bisphenols and chlorinated derivative standard solution in methanol:water $(50: 50, \mathrm{v} / \mathrm{v})$ and diglycidyl ethers in methanol:ammonium formate/formic acid buffer $(12.5 \mathrm{mM}, \mathrm{pH} 3.75 ; 50: 50 \mathrm{v} / \mathrm{v})$ at a concentration range of $0.01-1000 \mathrm{ng} \mathrm{mL}^{-1}$. Signal variability was corrected with the signal of the internal standard ${ }_{12} \mathrm{C}^{13}$-BPA and $\mathrm{d}_{6}$-BADGE for bisphenols and diglycidyl ethers, respectively. The slopes of these calibration curves were compared with the slope of calibration curves prepared by standard addition, using an appropriate Student's $t$-test [23].
The sensitivity of the method was calculated as three times of standard deviation of six blank determinations for the limit of detection (LOD) or ten times to calculate the limit of quantification (LOQ). The limits of the method were estimated from the respective LOD and LOQ taking into account the sample amount $(100 \mathrm{mg})$, extraction conditions and recoveries obtained for each analyte.

Since a reference-certified material of bisphenols in dust is unavailable, method accuracy was evaluated by calculating the recoveries in six aliquots of pooled dust samples fortified with bisphenols, chlorinated derivatives and diglycidyl ethers and subjected to the whole analytical process. Precision of the method, calculated as intra-day variation, was calculated as the square root of the mean of the average variance value obtained for the six aliquots of pooled dust samples analysed, and expressed as relative standard deviation (RSD).

\section{Occupational exposure risk assessment to bisphenol compounds}

In order to have a preliminary approach on the risk of exposure to bisphenols and derivatives of greenhouse workers, both the theoretical bioaccessibility $(\mathrm{Ba})$ of the compounds and the average daily dose (ADD) via dust ingestion were estimated. 
Bioaccessibility can be defined as the fraction of the total amount of an ingested substance that becomes accessible for absorption through the epithelial layer of the gastrointestinal tract. The following equation, described by Dong et al. [24], allows the estimation of $\mathrm{Ba}$ when $\log K_{\text {ow }}$ value of bisphenols ranges between 5 and 8 :

$B a=a+\frac{(b-a) *(8-\log \text { Kow })}{8-5}$

where the constants $a$ and $b$ are 0.2 and 0.8 respectively. For $\log K_{\text {ow }}>5$, Ba is assumed to be 0.8 ; whereas if $\log K_{\text {ow }}>8$, $\mathrm{Ba}$ is equal to 0.2 .

In the greenhouse cultivation sector, farm labours are grouped in a season, based on the specific requirements of each crop type. For this reason, seasonal workers frequently move within the European Union (EU) or even other countries like Morocco for working the whole year. Thus, the duration of working hours and working days per year for seasonal workers is extremely difficult to estimate. In this study, the average daily dose of bisphenols has been calculated under the hypothesis of an average working week of $37 \mathrm{~h}$ for 270 working days per year in the EU and 40 years of work [25]. The ADD was calculated according to the following equation:

$A D D=\frac{C * B a * \operatorname{Ing} R * E F * E D * E T}{B W * A T}$

where $C$ is the concentration of bisphenol found in dust $\left(\mathrm{ng} \mathrm{g}^{-1}\right), B a$ is the estimated theoretical bioaccessibility value for the compound; IngR is the ingestion of dust of an adult per day $\left(0.05 \mathrm{~g} \mathrm{day}^{-1}\right)$ [26]; $E F$ is the annual exposure frequency ( 270 days year $\left.^{-1}\right) ; E D$ is the lifetime exposure duration (40 years); $E T$ is the fraction of the day that seasonal workers spend working in greenhouses (0.38); $B W$ is the average body weight of workers (70.8 $\mathrm{kg}$ [27]); and $A T$ is the total number of days considered for ADD estimation (270 days year ${ }^{-1}$ mul- $^{-}$ tiplied for ED for non-carcinogenic effects) [28].

\section{Results and discussion}

\section{Optimisation of bisphenol extraction from dust by hexanol-based SUPRAS-RAM}

Hexanol-based SUPRAS-RAM is a nanostructured solvent that is spontaneously formed. The amphiphile molecules of hexanol self-assemble in THF above the critical aggregation concentration. The addition of water promotes their coacervation and SUPRAS separates from bulk solution in a lighter new phase [20]. This SUPRAS consists of inverted hexagonal aggregates where the hydroxyl groups of hexanol are surrounding the aqueous cavities and the hydrocarbon chains are dispersed in THF (Fig. 2). The synthetic environment of SUPRAS (i.e. THF/water ratio) determines the size of the water cavity of the aggregates, and consequently, both the chemical composition and properties of this SUPRAS are tuneable [19]. On the other hand, it behaves as a restricted access material (SUPRASRAM) by removing macromolecules from the extract through chemical and physical mechanisms. Thus, proteins precipitate by the action of THF (reduces the solution dielectric constant) and hexanol (forms mixed complex with proteins), while polar macromolecules are excluded by controlling the size of the aqueous cavity [29].

A pool of dust samples from samples 1-5 was prepared for the optimisation and in-house validation of the method. The main variables of the proposed analytical methodology affecting the quantification of bisphenols in dust were evaluated and optimised. The existing inter- and intra-variable relations are complex and unknown, so a multivariate analysis was performed. The variables were optimised based on the obtained results of the experiments programmed by the multivariant Box-Behnken response surface design model (Minitab Statistical Software. Free software. 20 version).

For the optimisation, $100 \mathrm{mg}$ of pooled dust sample and $10 \%$ of hexanol were established. The following variables were investigated: (i) the percentage of THF (10-60\%) because it controls the size of the aqueous cavity, which has a significant impact on SUPRAS extraction and cleanup capabilities. The selection of the value range for THF was based on the hexanol-based SUPRAS phase diagram [20]. (ii) The SUPRAS volume $(0.05-0.4 \mathrm{~mL})$ to perform the extraction. The value range was established trying to reach a balance between maximum extraction efficiency and low limits of quantification for the method (MLQ). (iii) The time of extraction in a range of 1 to $30 \mathrm{~min}$, the usual extraction times required in SUPRAS-methodologies. (iv) The volume of the reconstitution solution for bisphenol solubilisation $(0.075-0.3 \mathrm{~mL})$. The value range was selected under two considerations: to obtain enough volume for performing chromatographic analysis by triplicate (if necessary) and to achieve the highest possible concentration factors and recoveries for bisphenols.

Since the relations of the variables were unknown, all the responses from the different variables were considered equally important and the weight and importance were all set at 1 . With these conditions, the Box-Behnken model proposed 27 experimental runs, including duplicates, with a random combination of the values of the studied variables. Values approaching $100 \%$ of total recovery (extraction+selectivity) were selected as optimal value, considering it as the target value. Table 2 shows the results obtained for the optimisation of extraction parameters, including fit values with their corresponding standard errors, the confidence and predicted intervals and desirability. The 
Table 2 Response optimisation obtained for bisphenols, chlorinated derivatives and diglycidyl ethers by multivariate analysis

\begin{tabular}{llllll}
\hline Analyte & Fit & Standard error & $\begin{array}{l}\text { Confidence inter- } \\
\text { val (95\%) }\end{array}$ & $\begin{array}{l}\text { Predicted inter- } \\
\text { val (95\%) }\end{array}$ & Desirability \\
\hline BPA & 96 & 6.4 & $90.5-114.9$ & $74.7-145.2$ & 0.9638 \\
BPB & 97 & 18.9 & $46.5-98.2$ & $33.2-184.9$ & 0.9747 \\
BPE & 109 & 10.8 & $60.2-117.4$ & $44.0-133.7$ & 0.8313 \\
BPF & 99 & 7.7 & $66.3-130.4$ & $59.8-186.9$ & 0.9976 \\
BPP & 94 & 7.3 & $78.1-109.8$ & $67.3-130.7$ & 0.9440 \\
BPS & 95 & 9.53 & $61.1-119.6$ & $76.8-146.9$ & 0.9950 \\
BPZ & 93 & 11.0 & $70.8-118.7$ & $54.4-135.1$ & 0.9598 \\
BPAF & 106 & 7.7 & $86.0-119.5$ & $74.6-131.4$ & 0.9978 \\
BPAP & 107 & 9.9 & $74.0-117.5$ & $59.1-132.4$ & 0.9983 \\
MCBPA & 93 & 16.4 & $65.1-136.5$ & $40.6-161.0$ & 0.9476 \\
DCBPA & 87 & 10.3 & $60.2-95.1$ & $44.8-120.5$ & 0.9297 \\
TCBPA & 96 & 10.5 & $76.7-122.6$ & $60.9-138.4$ & 0.9585 \\
TeCBPA & 98 & 7.34 & $72.4-104.4$ & $61.4-125.4$ & 0.9687 \\
BADGE & 101 & 10.0 & $75.8-119.4$ & $60.8-134.4$ & 0.9676 \\
BADGE·H2O & 97 & 20.3 & $58.3-146.6$ & $27.9-176.9$ & 0.9489 \\
BADGE·2H2O & 107 & 13.9 & $66.7-117.3$ & $52.8-132.3$ & 0.9909 \\
BADGE·HCl & 90 & 7.3 & $74.1-105.7$ & $63.2-116.6$ & 0.9697 \\
BADGE·2HCl & 95 & 10.1 & $69.4-113.5$ & $54.2-128.7$ & 0.9140 \\
BADGE·HCl·H2O & 86 & 14.7 & $69.8-108.7$ & $44.4-125.1$ & 0.8448 \\
BFDGE & 102 & 9.5 & $80.4-121.9$ & $66.2-136.1$ & 0.9706 \\
BFDGE·2H2O & 108 & 9.9 & $78.2-121.6$ & $63.2-136.6$ & 0.9994 \\
\hline
\end{tabular}

analysis of the obtained results gives optimal values for performing the extraction of bisphenols from dust $0.4 \mathrm{~mL}$ of SUPRAS with a composition of $10 \%$ hexanol and $20 \%$ THF; and $0.16 \mathrm{~mL}$ of reconstitution solution. Any influence related to the variable of extraction time was observed in the range of 5-30 min; thus, a time of $10 \mathrm{~min}$ was selected as optimal.

\section{Analytical method performance}

The performance of the analytical method was evaluated according to the procedures specified in the section "Materials and methods". The correlation coefficients $(r)$ for the calibration curves were in the range 0.9808-0.9990, indicating a good fit (Table 3). The calculated Student's $t$-values obtained for the comparison of the slopes of external calibration and the standard addition method (1.21-2.29) were all lower than the critical $t$-value (2.98) for a $95 \%$ confidence level. So, no significant differences were found between the calibration curves obtained by both methods, and consequently matrix components were not expected to interfere in the quantification of bisphenols in dust.

The values obtained for LOD and LOQ ranged from 0.009 to 0.032 and 0.02 to $0.09 \mathrm{ng} \mathrm{mL}^{-1}$ for bisphenols, 0.012-0.027 and 0.03-0.08 $\mathrm{ng} \mathrm{mL}^{-1}$ for chlorinated derivatives; and $0.004-0.051$ and $0.01-0.15 \mathrm{ng} \mathrm{mL}^{-1}$ for diglycidyl ethers, respectively (Table 3). The MQL ranged from 0.02 to 0.08 and 0.03 to $0.07 \mathrm{ng} \mathrm{g}^{-1}$ for bisphenols and chlorinated derivatives; and $0.01-0.13 \mathrm{ng} \mathrm{g}^{-1}$ for diglycidyl ethers, respectively.

Recoveries for six aliquots of pooled dust samples, fortified with bisphenols, chlorinated derivatives and diglycidyl ethers, were in the ranges 93-109 and 87-98\% for bisphenols and chlorinated derivatives and $86-108 \%$ for diglycidyl ethers, respectively. A typical chromatogram of a dust sample fortified is shown in Fig. 3. Intra-day variability ranged between 1-8 and 2-15\% for bisphenols and chlorinated derivatives and 3-10\% for diglycidyl ethers, respectively. Table 3 shows the analytical parameter values for each bisphenol compound.

\section{Analysis of greenhouse dust samples}

Five dust samples collected in two different greenhouses were analysed by the proposed analytical methodology. Table 4 shows the concentration found, expressed as the mean value of three determinations ( $\left.\mathrm{ng} \mathrm{g}^{-1}\right)$, along with their respective standard deviations. Only two bisphenols (BADGE·HCl and BADGE.2HCl) were not found in any of the analysed samples. As it was expected, BPA was the most abundant bisphenol in all the samples collected from the different sites and materials of the greenhouses (concentrations so high as $5275 \mathrm{ng} \mathrm{g}^{-1}$ were found), with $100 \%$ of frequency of detection. The second most abundant (up to $1850 \mathrm{ng} \mathrm{g}^{-1}$ ) was a derivative of BADGE (BADGE.H2O). 
Table 3 Analytical parameters of the in-house method validation

\begin{tabular}{llllllll}
\hline Analyte & $\begin{array}{l}t_{\mathrm{R}} \\
(\mathrm{min})\end{array}$ & $r$ & $\begin{array}{l}\text { LOD } \\
\left.(\mathrm{ng} \mathrm{mL})^{-1}\right)\end{array}$ & $\begin{array}{l}\text { LOQ } \\
\left(\mathrm{ng} \mathrm{mL}^{-1}\right)\end{array}$ & $\begin{array}{l}\text { MQL } \\
\left(\mathrm{ng} \mathrm{g}^{-1}\right)\end{array}$ & $\begin{array}{l}\text { Recovery } \\
(\%)\end{array}$ & $\begin{array}{l}\text { RSD } \\
(\%)\end{array}$ \\
\hline BPA & 12.37 & 0.9945 & 0.015 & 0.04 & 0.04 & 96 & 4 \\
BPB & 12.92 & 0.9926 & 0.009 & 0.02 & 0.02 & 97 & 5 \\
BPE & 11.87 & 0.9980 & 0.011 & 0.04 & 0.03 & 109 & 5 \\
BPF & 11.28 & 0.9808 & 0.032 & 0.09 & 0.08 & 99 & 2 \\
BPP & 16.69 & 0.9979 & 0.013 & 0.04 & 0.04 & 94 & 8 \\
BPS & 7.81 & 0.9990 & 0.009 & 0.03 & 0.03 & 95 & 7 \\
BPZ & 13.99 & 0.9990 & 0.010 & 0.03 & 0.03 & 93 & 1 \\
BPAF & 14.50 & 0.9988 & 0.011 & 0.04 & 0.03 & 106 & 1 \\
BPAP & 13.73 & 0.9931 & 0.012 & 0.04 & 0.03 & 107 & 3 \\
MCBPA & 13.40 & 0.9924 & 0.027 & 0.08 & 0.07 & 93 & 2 \\
DCBPA & 14.64 & 0.9962 & 0.017 & 0.05 & 0.05 & 87 & 15 \\
TCBPA & 15.77 & 0.9938 & 0.015 & 0.04 & 0.04 & 96 & 7 \\
TeCBPA & 17.01 & 0.9977 & 0.012 & 0.03 & 0.03 & 98 & 6 \\
BADGE & 15.72 & 0.9959 & 0.006 & 0.02 & 0.02 & 101 & 9 \\
BADGE·H2O & 12.65 & 0.9968 & 0.004 & 0.01 & 0.01 & 97 & 4 \\
BADGE·2H2O & 11.55 & 0.9925 & 0.033 & 0.09 & 0.07 & 107 & 6 \\
BADGE·HCl & 15.55 & 0.9978 & 0.051 & 0.13 & 0.12 & 90 & 6 \\
BADGE·2HCl & 15.17 & 0.9982 & 0.045 & 0.13 & 0.12 & 95 & 3 \\
BADGE·HCl·H2O & 13.22 & 0.9918 & 0.037 & 0.10 & 0.10 & 86 & 10 \\
BFDGE & 14.65 & 0.9948 & 0.051 & 0.15 & 0.13 & 102 & 4 \\
BFDGE·2H2O & 9.98 & 0.9892 & 0.046 & 0.11 & 0.09 & 108 & 7 \\
\hline
\end{tabular}

$t_{R}$ time of retention; $r$ correlation coefficient; $L O D$ instrumental limit of detection; $L O Q$ instrumental limit of quantification; $M Q L$ method limit of quantification
Both high levels of concentration were detected in dust collected from lamps of the sawtooth greenhouse. A possible reason is the position of the lamps, which are hung from the ceiling in the centre of the greenhouse, which may make easier the deposition of contaminants coming from the whole greenhouse. On the other hand, it is interesting that the four bisphenol-chlorinated derivatives have been identified in all the samples. Plant protection and biocidal products may contribute to the BPA transformation in its chlorinated forms.

Regarding the type of greenhouse, unfortunately, there were no sufficient samples for the shade house type, so it was not possible to establish any correlation or comparison material/ location/bisphenol concentration. However, focusing on samples collected from wall sample 2 and sample 5, of sawtooth and shade greenhouse, respectively; BPA concentration in sample 2 is five times higher than the detected in sample 5. Important parameters affecting chemical leaching from plastic materials to dust are different in both greenhouses, such as ventilation, humidity and radiation. Despite these different environmental conditions, the concentrations for the rest of the bisphenols were similar. Thus differences in BPA concentration could be more related to the material of the greenhouse.

The predominance of BPA and their derivatives in greenhouse dust on the rest of bisphenol analogues was clear (e.g. BPA, MCPA, BADGE $\cdot \mathrm{H}_{2} \mathrm{O}, \mathrm{BADGE} \cdot 2 \mathrm{H}_{2} \mathrm{O}$, $\left.\mathrm{BADGE} \cdot \mathrm{HCl} \cdot \mathrm{H}_{2} \mathrm{O}\right)$ although the concentrations of other bisphenols and their derivatives (e.g. BPF and BFDGE $2 \mathrm{H}_{2} \mathrm{O}$ ) were significant. The obtained results bring to light the importance of evaluating the bisphenol risk exposure from greenhouses.

\section{Greenhouse workers exposure to bisphenols via dust ingestion}

Humans are exposed to dust-related chemicals via inhalation, dermal and ingestion. Inhalation exposure to dust is minimum, thanks to the water spread spots located in the ceiling of greenhouses for humidity control, which reduces dust dispersion. On the other hand, due to the use of phytosanitary products, all workers are encouraged to wear individual protection equipment as part of the strict protocol of measures for the prevention of occupational risks. This, along with the lack of information related to the fraction of bisphenols that is absorbed by skin, the human exposure to bisphenols via dermal absorption was not considered in this study. Thus, we only focused on exposure via ingestion.

The estimated ADD values for each bisphenol compound are shown in Table 5 . In the case of the sawtooth 
Fig. 3 Typical LC-ESI-MS/ MS chromatogram of a fortified dust sample. a Bisphenols and chlorinated bisphenols, and $\mathbf{b}$ diglycidyl ether compounds
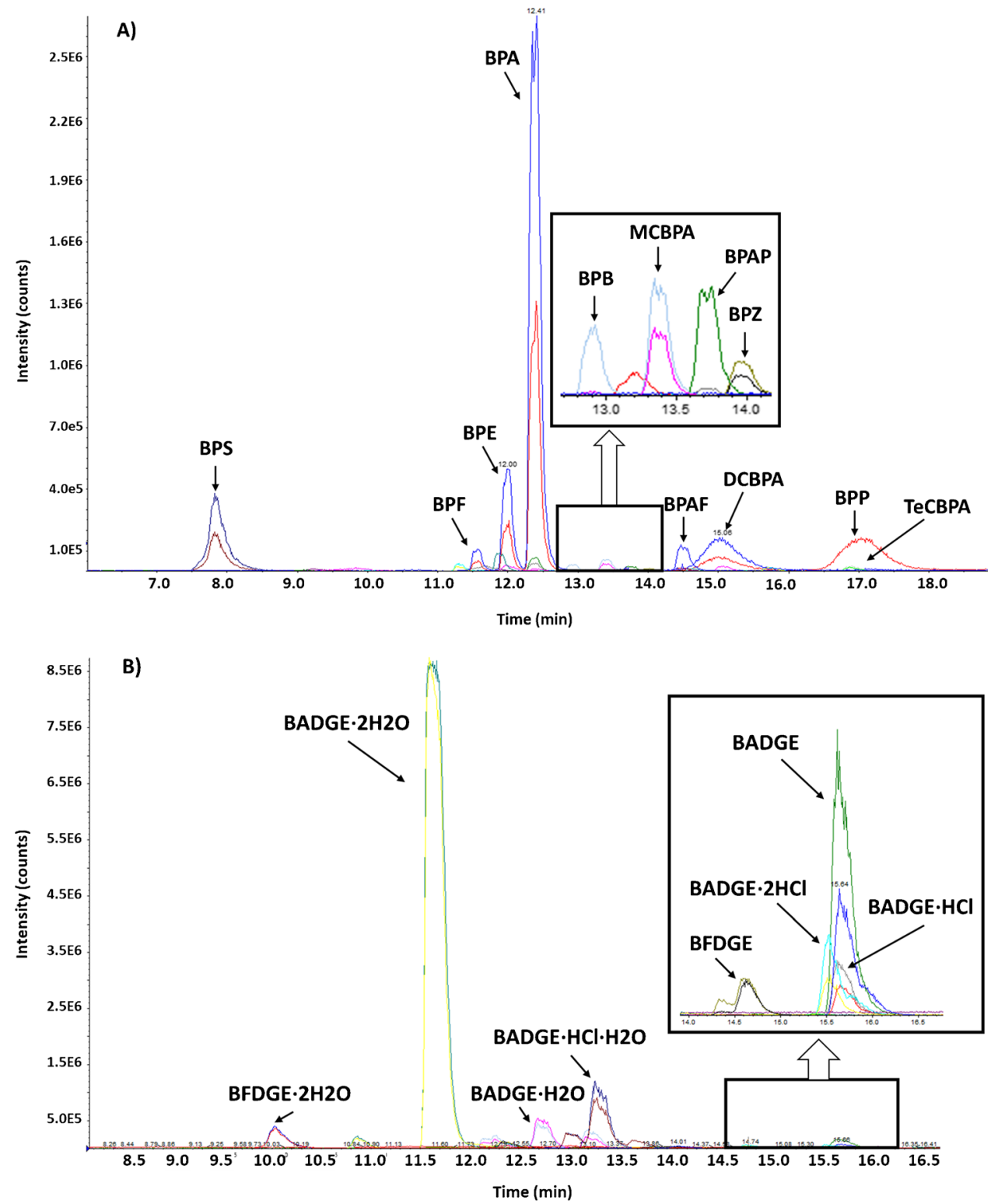

greenhouse, the ADD values have been calculated considering the sum of concentrations of found bisphenols from samples 1-4, while concentrations found in sample 5 were used for the estimation of ADD in the shade greenhouse. For the first greenhouse, BPA (47.81 $\mathrm{ng} \mathrm{kg}^{-1} \mathrm{day}^{-1}$ ) and BADGE-2H2O (15.95 $\mathrm{ng} \mathrm{kg}^{-1}$ day $^{-1}$ ) presented the highest average daily dose via dust ingestion, having both compounds a DF of $100 \%$. However, in the shade greenhouse, the highest ADD were calculated for BPA $\left(0.33 \mathrm{ng} \mathrm{kg}^{-1} \mathrm{day}^{-1}\right)$ and BPP (0.31 $\left.\mathrm{ng} \mathrm{kg}^{-1} \mathrm{day}^{-1}\right)$, while BADGE.2H2O $\left(0.08 \mathrm{ng} \mathrm{kg}^{-1} \mathrm{day}^{-1}\right)$ was two orders of magnitude lower.

In 2018, the European Food Safety Authority (EFSA) reviewed the BPA exposure level considered as safe for humans and established a new tolerable daily intake (TDI) of $4 \cdot 10^{3} \mathrm{ng} \mathrm{kg}^{-1} \mathrm{day}^{-1}$ [30]. The estimated ADD for all bisphenols were below the suggested BPA TDI; thus, in theory, there is no risk chemical for greenhouse workers. However, it is necessary to consider that EFSA defines TDI as the maximum amount of a substance to which any individual can be exposed every day of his/her life, through all possible sources, without any risk to his/her health [30]. Moreover, previously reported ADD for indoor dust were much lower than the values estimated in this study. For example, Wang et al. [16] reported an average exposure to BPA via residential dust ingestion, calculated in samples collected from twelve countries, in the range $0.03-0.85 \mathrm{ng} \mathrm{kg}^{-1} \mathrm{day}^{-1}$, which is up to four orders of magnitude lower than the estimated DDA for greenhouse dust (47.81-0.33 $\mathrm{ng} \mathrm{kg}^{-1} \mathrm{day}^{-1}$ ). This fact pointed out the great potential contribution of this source to the total exposure of greenhouse workers. 
Table 4 Concentrations found of bisphenols, chlorinated and diglycidyl ethers along with their respective standard deviation and detection frequency in greenhouse dust

\begin{tabular}{|c|c|c|c|c|c|c|c|}
\hline \multirow[t]{2}{*}{ Analyte } & \multicolumn{5}{|c|}{ Concentration found $\left(\mathrm{ng} \mathrm{g}^{-1}\right) \pm \mathrm{SD}$} & \multirow[t]{2}{*}{$\sum \mathrm{BPs}^{\mathrm{a}}$} & \multirow[t]{2}{*}{$\mathrm{DF}(\%)$} \\
\hline & Sample 1 & Sample 2 & Sample 3 & Sample 4 & Sample 5 & & \\
\hline BPA & $5275 \pm 33$ & $223 \pm 1$ & $18 \pm 2$ & $125 \pm 10$ & $38.8 \pm 0.1$ & 5641 & 100 \\
\hline BPB & $7.0 \pm 0.5$ & $2.2 \pm 0.2$ & $2.8 \pm 0.2$ & $1.48 \pm 0.06$ & $2.64 \pm 0.07$ & 13.48 & 100 \\
\hline BPE & $<\mathrm{MQL}$ & nd & nd & nd & $3.2 \pm 0.2$ & - & 40 \\
\hline $\mathrm{BPF}$ & $55 \pm 1$ & nd & nd & $6.6 \pm 0.3$ & nd & 61.60 & 40 \\
\hline ВРP & $4.9 \pm 0.4$ & $0.62 \pm 0.05$ & $4.1 \pm 0.3$ & $1.3 \pm 0.1$ & $37 \pm 2$ & 10.92 & 100 \\
\hline BPS & $0.68 \pm 0.07$ & nd & nd & nd & $<\mathrm{MQL}$ & 0.68 & 40 \\
\hline BPZ & nd & nd & nd & nd & $9.7 \pm 0.3$ & - & 20 \\
\hline BPAF & $0.25 \pm 0.01$ & $0.22 \pm 0.01$ & $0.153 \pm 0.003$ & $0.336 \pm 0.003$ & $0.91 \pm 0.02$ & 0.96 & 100 \\
\hline BPAP & nd & $<\mathrm{MQL}$ & nd & $<\mathrm{MQL}$ & nd & - & 40 \\
\hline MCBPA & $38 \pm 2$ & $1.9 \pm 0.1$ & $<\mathrm{MQL}$ & $3.74 \pm 0.09$ & $0.30 \pm 0.01$ & 43.64 & 100 \\
\hline DCBPA & $1.7 \pm 0.2$ & $0.41 \pm 0.06$ & $0.33 \pm 0.06$ & $0.67 \pm 0.04$ & $0.6 \pm 0.1$ & 3.11 & 100 \\
\hline TCBPA & $0.81 \pm 0.07$ & $0.39 \pm 0.03$ & $0.291 \pm 0.009$ & $0.42 \pm 0.03$ & $0.51 \pm 0.04$ & 1.91 & 100 \\
\hline TeCBPA & $0.46 \pm 0.03$ & $0.27 \pm 0.02$ & $0.25 \pm 0.02$ & $0.52 \pm 0.03$ & $0.28 \pm 0.02$ & 1.50 & 100 \\
\hline BADGE & nd & nd & nd & nd & $0.60 \pm 0.06$ & - & 20 \\
\hline BADGE.H2O & $148 \pm 2$ & $1.22 \pm 0.07$ & $0.69 \pm 0.02$ & $<\mathrm{MQL}$ & $0.84 \pm 0.04$ & 149.91 & 100 \\
\hline BADGE·2H2O & $1850 \pm 160$ & $20 \pm 1$ & $12.4 \pm 0.3$ & $2.5 \pm 0.2$ & $9.5 \pm 0.8$ & 1882 & 100 \\
\hline BADGE $\cdot \mathrm{HCl}$ & nd & nd & nd & nd & nd & - & 0 \\
\hline BADGE $2 \mathrm{HCl}$ & nd & nd & nd & nd & nd & - & 0 \\
\hline BADGE $\cdot \mathrm{HCl} \cdot \mathrm{H} 2 \mathrm{O}$ & $305 \pm 13$ & $2.29 \pm 0.03$ & $4.1 \pm 0.4$ & nd & $4.3 \pm 0.6$ & 311.39 & 80 \\
\hline BFDGE & nd & nd & nd & nd & $3.1 \pm 0.3$ & - & 20 \\
\hline BFDGE $2 \mathrm{H} 2 \mathrm{O}$ & $12 \pm 1$ & $5.2 \pm 0.3$ & $4.4 \pm 0.2$ & $1.2 \pm 0.1$ & $3.6 \pm 0.3$ & 22.8 & 100 \\
\hline
\end{tabular}

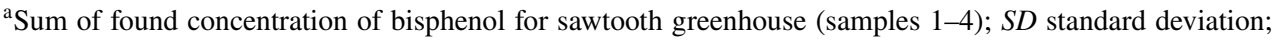
$D F$ detection frequency; $n d$ non detected; $n=3$
Table 5 Theorethical bioaccessibility values and the estimated average daily dose via dust ingestion for all the targeted bisphenols

\begin{tabular}{llll}
\hline Analyte & Ba & $\begin{array}{l}\text { ADD sawtooth } \\
\text { greenhouse } \\
\left(\mathrm{ng} \mathrm{kg}^{-1} \mathrm{day}^{-1}\right)\end{array}$ & $\begin{array}{l}\text { ADD shade greenhouse } \\
\left(\mathrm{ng} \mathrm{kg}^{-1} \mathrm{day}^{-1}\right)\end{array}$ \\
\hline BPA & 0.8 & 47.81 & 0.33 \\
BPB & 0.8 & 0.11 & 0.02 \\
BPE & 0.8 & - & 0.027 \\
BPF & 0.8 & 0.52 & - \\
BPP & 0.49 & 0.09 & 0.31 \\
BPS & 0.8 & 0.006 & - \\
BPZ & 0.8 & - & 0.08 \\
BPAF & 0.8 & 0.008 & 0.008 \\
BPAP & 0.8 & - & - \\
MCBPA & 0.8 & 0.37 & 0.003 \\
DCBPA & 0.79 & 0.026 & 0.005 \\
TCBPA & 0.66 & 0.016 & 0.004 \\
TeCBPA & 0.52 & 0.013 & 0.002 \\
BADGE & 0.8 & - & 0.005 \\
BADGE·H2O & 0.8 & 1.27 & 0.007 \\
BADGE·2H2O & 0.8 & 15.95 & 0.08 \\
BADGE·HCl & 0.8 & - & - \\
BADGE·2HCl & 0.8 & - & - \\
BADGE·HCl-H2O & 0.8 & 2.64 & 0.03 \\
BFDGE & 0.8 & - & 0.026 \\
BFDGE-2H2O & 0.8 & 0.19 & 0.03 \\
\hline
\end{tabular}

$B a$ theoretical bioaccessibility; $A D D$ average daily dose
However, due to the limited number of samples analysed in this study, the obtained results should warrant caution. More studies are required to assess the role that greenhouse dust plays in the bisphenol occupational exposure field.

\section{Conclusions}

The exposure to bisphenol, chlorinated derivatives and diglycidyl ethers of humans is being strongly investigated by the Scientific Community. However, many potential sources of bisphenol exposure remain unknown. The analytical methodology proposed in this study, based on the use of SUPRAS and LC-MS/MS, has been successfully applied to the determination of twenty-one bisphenols in greenhouses dust. Building materials of greenhouses and the typical environmental conditions (high temperature, humidity, radiation, etc.) makes them potential sources of contaminants. Despite the calculated ADD values being under the tolerable daily intake proposed by EFSA, they were above the previously ADD values reported via indoor dust. Although it is difficult to draw definitive conclusions due to the reduced number of analysed dust samples, this study brings to light the importance of assessing the role that greenhouse dust plays in the bisphenol occupational exposure field for reducing the occupational risk exposure to a minimum. 
Acknowledgements The authors thank all the dust donors of the study. This work was supported by the Andalusian Department of Knowledge, Innovation and University (P18-RT-2654). Dr Caballero-Casero acknowledges their post-doctoral contract from the Andalusian Government (Ref. Doc_00289).

Funding Open Access funding provided thanks to the CRUECSIC agreement with Springer Nature. University of Córdoba/CBUA

\section{Declarations}

Competing interests The authors declare no competing interests.

Open Access This article is licensed under a Creative Commons Attribution 4.0 International License, which permits use, sharing, adaptation, distribution and reproduction in any medium or format, as long as you give appropriate credit to the original author(s) and the source, provide a link to the Creative Commons licence, and indicate if changes were made. The images or other third party material in this article are included in the article's Creative Commons licence, unless indicated otherwise in a credit line to the material. If material is not included in the article's Creative Commons licence and your intended use is not permitted by statutory regulation or exceeds the permitted use, you will need to obtain permission directly from the copyright holder. To view a copy of this licence, visit http://creativecommons.org/licenses/by/4.0/.

\section{References}

1. Gore AC, Chappell VA, Fenton SE, Flaws JA, Nadal A, Prins GS, Toppari J, Zoeller RT. EDC-2: The Endocrine Society's second scientific statement on endocrine-disrupting chemicals. Endocr Rev. 2015;36(6):1-150. https://doi.org/10.1210/ER.2015-1010.

2. COMMISSION REGULATION (EU) 2016/ 1179 - of 19 July 2016 - amending, for the purposes of its adaptation to technical and scientific progress, Regulation (EC) No 1272 / 2008 of the European Parliament and of the Council.

3. Cimmino I, Fiory F, Perruolo G, Miele C, Beguinot F, Formisano P, Oriente F. Potential mechanisms of bisphenol A (BPA) contributing to human disease. Int J Mol Sci. 2020;21(16):5761. https:// doi.org/10.3390/IJMS21165761.

4. Vervliet P, Gys C, Caballero-Casero N, Covaci A. Current-use of developers in thermal paper from 14 countries using liquid chromatography coupled to quadrupole time-of-flight mass spectrometry. Toxicology. 2019;416:54-61. https://doi.org/10.1016/j. tox.2019.02.003.

5. Vela-Soria, F., Ballesteros, O., Zafra-Gómez, A., Ballesteros, L., Navalón, A. (2014). UHPLC-MS/MS method for the determination of bisphenol A and its chlorinated derivatives, bisphenol S, parabens, and benzophenones in human urine samples. Anal. Bioanal. Chem. 2014 406:15, 406(15), 3773-3785. https://doi.org/10. 1007/S00216-014-7785-9

6. Cheng, Y., Nie, X. mei, Wu, H. qiu, Hong, Y. he, Yang, B. cheng, Liu, T., Zhao, D., Wang, J. feng, Yao, G. hong, Zhang, F. (2017). A high-throughput screening method of bisphenols, bisphenols digycidyl ethers and their derivatives in dairy products by ultrahigh performance liquid chromatography-tandem mass spectrometry. Anal. Chim. Acta, 950, 98-107. https://doi.org/10.1016/J. ACA.2016.11.006

7. Vasiljevic T, Harner T. Bisphenol A and its analogues in outdoor and indoor air: properties, sources and global levels. Sci Total Environ. 2021;789:148013. https://doi.org/10.1016/J.SCITO TENV.2021.148013.
8. Caballero-Casero N, Lunar L, Rubio S. Analytical methods for the determination of mixtures of bisphenols and derivatives in human and environmental exposure sources and biological fluids. A review Anal Chim Acta. 2016;908:22-53. https://doi.org/10. 1016/j.aca.2015.12.034.

9. Rochester JR, Bolden AL. Bisphenol S and F: a systematic review and comparison of the hormonal activity of bisphenol a substitutes. Environ Health Perspect. 2015;123(7):643-50. https://doi. org/10.1289/EHP.1408989.

10. Lucattini L, Poma G, Covaci A, de Boer J, Lamoree MH, Leonards PEG. A review of semi-volatile organic compounds (SVOCs) in the indoor environment: occurrence in consumer products, indoor air and dust. Chemosphere. 2018;201:466-82. https://doi. org/10.1016/J.CHEMOSPHERE.2018.02.161.

11. D'Hollander W, Roosens L, Covaci A, Cornelis C, Reynders H, Van CK, de Voogt P, Bervoets L. Brominated flame retardants and perfluorinated compounds in indoor dust from homes and offices in Flanders. Belgium Chemosphere. 2010;81(4):478-87. https:// doi.org/10.1016/J.CHEMOSPHERE.2010.07.043.

12. Rauert C, Harrad S. Mass transfer of PBDEs from plastic TV casing to indoor dust via three migration pathways - a test chamber investigation. Sci Total Environ. 2015;536:568-74. https://doi. org/10.1016/J.SCITOTENV.2015.07.050.

13. Weschler CJ, Nazaroff WW. Semivolatile organic compounds in indoor environments. Atmos Environ. 2008;42(40):9018-40. https://doi.org/10.1016/J.ATMOSENV.2008.09.052.

14. Melymuk L, Demirtepe H, Jílková SR. Indoor dust and associated chemical exposures. Curr Opin Environ Sci Health. 2020;15:1-6. https://doi.org/10.1016/J.COESH.2020.01.005.

15. US Environmental Protection Agency. (2011). Exposure Factors Handbook: 2011 Edition. U.S. Environmental Protection Agency, EPA/600/R-(September), 1-1466. EPA/600/R-090/052F

16. Wang W, Abualnaja KO, Asimakopoulos AG, Covaci A, Gevao B, Johnson-Restrepo B, Kumosani TA, Malarvannan G, Minh TB, Moon HB, Nakata H, Sinha RK, Kannan K. A comparative assessment of human exposure to tetrabromobisphenol A and eight bisphenols including bisphenol A via indoor dust ingestion in twelve countries. Environ Int. 2015;83:183-91. https://doi.org/10.1016/j. envint.2015.06.015.

17. Bousoumah R, Leso V, Iavicoli I, Huuskonen P, Viegas S, Porras SP, Santonen T, Frery N, Robert A, Ndaw S. Biomonitoring of occupational exposure to bisphenol A, bisphenol S and bisphenol F: a systematic review. Sci Total Environ. 2021;783:146905. https://doi.org/10.1016/J.SCITOTENV.2021.146905.

18. Rubio $S$ Twenty years of supramolecular solvents in sample preparation for chromatography: achievements and challenges ahead. Anal Bioanal Chem. 2020:6037-6058. https://doi.org/10.1007/ s00216-020-02559-y

19. Ballesteros-Gómez A, Rubio S. Environment-responsive alkanolbased supramolecular solvents: characterization and potential as restricted access property and mixed-mode extractants. Anal Chem. 2012;84(1):342-9. https://doi.org/10.1021/ac2026207.

20. Salatti-Dorado JÁ, Caballero-Casero N, Sicilia MD, Lunar ML, Rubio S. The use of a restricted access volatile supramolecular solvent for the LC/MS-MS assay of bisphenol $\mathrm{A}$ in urine with a significant reduction of phospholipid-based matrix effects. Anal Chim Acta. 2017;950:71-9. https://doi.org/10.1016/j.aca.2016. 11.026.

21. Caballero-Casero N, Rubio S. Comprehensive supramolecular solvent-based sample treatment platform for evaluation of combined exposure to mixtures of bisphenols and derivatives by liquid chromatography-tandem mass spectrometry. Anal Chim Acta. 2021;1144:14-25. https://doi.org/10.1016/j.aca.2020.11.057.

22. Gallart_Ayala, H., Moyano, E., \& Galceran, E. (2010). Multiple-stage mass spectrometry analysis of bisphenol A diglycidyl ether, bisphenol F diglycidyl ether and their derivatives. Rapid 
Commun. Mass Spectrom. 24(23), 3469-3477. https://doi.org/10. 1002/RCM.480

23. Rodríguez LC, Campaña AMG, Barrero FA, Linares CJ, Ceba MR. Validation of an analytical instrumental method by standard addition methodology. J AOAC Int. 1995;78(2):471-6. https://doi. org/10.1093/JAOAC/78.2.471.

24. Dong T, Zhang Y, Jia S, Shang H, Fang W, Chen D, Fang M. Human indoor exposome of chemicals in dust and risk prioritization using EPA's ToxCast Database. Environ Sci Technol. 2019;53(12):7045-54. https://doi.org/10.1021/ACS.EST.9B002 80.

25. Hours of work - annual statistics - Statistics Explained. https://ec. europa.eu/eurostat/statistics-explained/index.php?title=Hours_of work_-_annual_statistics. Accessed 27/09/2021.

26. USEPA. (2017). Exposure Factors Handbook Chapter 5 (Update): Soil and Dust Ingestion. U.S. EPA Office of Research and Development, Washington, DC, EPA/600/R-17/384F, 2017. https:// www.epa.gov/sites/production/files/2018-01/documents/efh-chapt er05_2017.pdf. Accessed 27/09/2021.

27. Walpole, S. C., Prieto-Merino, D., Edwards, P., Cleland, J., Stevens, G., Roberts, I. (2012). The weight of nations: an estimation of adult human biomass. BMC Public Health 2012 12:1, 12(1), 1-6. https://doi.org/10.1186/1471-2458-12-439

28. Besis A, Christia C, Poma G, Covaci A, Samara C. Legacy and novel brominated flame retardants in interior car dust - implications for human exposure. Environ Pollut. 2017;230:871-81. https://doi.org/10.1016/J.ENVPOL.2017.07.032.

29. García-Fonseca S, Rubio S. Restricted access supramolecular solvents for removal of matrix-induced ionization effects in mass spectrometry: application to the determination of Fusarium toxins in cereals. Talanta. 2016;148:370-9. https://doi.org/10.1016/J. TALANTA.2015.11.014.

30. EFSA. (2015). What potential health effects of BPA has EFSA identified? EFSA's risk assessment in more detail How did EFSA's experts calculate the new TDI? https://doi.org/10.2805/075460

Publisher's note Springer Nature remains neutral with regard to jurisdictional claims in published maps and institutional affiliations. 